\title{
Sustainability and Finance: Environment, Social, and Governance (ESG)
}

In the last few years, the focus on Environment, Social, and Governance (ESG) investment and socially responsible investment (SRI) has "exploded". How and to which extent investment criteria are taking into account are relevant for sustainable development.

Even though terms like ESG, SRI, and ethical investment seem new, some of the first examples of socially responsible investment can be traced back to the 1760s, when Quakers, a Christian community, decided not to invest money in companies which made products using slave labor. Later, companies involved in issues associated with unacceptable civiland women' rights and political issues have been excluded from investments by concerned citizens. This type of exclusion has been sporadic, and many based on individual beliefs. Over the past 20 years, ESG has attracted more attention as a way to reduce risk and detect new business opportunities. Also, the fact that the world's largest sovereign wealth fund, Norway's Government Pension Fund Global, introduced Ethical guidelines further increased the awareness and interest in ESG, SRI, and ethical investment. Recognizing the critical role and responsibility of investors in the pursuit of sustainable development, the UN initiative Principles for Responsible Investment (PRI) was launched in 2006. The PRI is an international network of more than 1700 signatory investors 
representing clients that control more than half of the world's wealth. The first of the six PRI principles illustrates the commitment required of its signatories to be part of this network: "We will incorporate ESG issues into investment analysis and decision-making processes".

Investors commitment to the ESG is reflected in the growth of investor sustainability strategies. In 2012, only one of nine dollars under professional management in the United States had some form of sustainable investment strategy. This number increased to one out of every six dollars in 2014, and in 2018, one out of four dollars under professional management had some sort of responsible investment strategy. In 2020 one in three dollars (33 percent) of the total US assets under professional management use sustainable investing strategies (US SIF: The Forum for Sustainable and Responsible Investment, 2020).

In 2021, the Net-Zero Banking Alliance was established representing over 40 percent of global banking assets. These financial institutions are now committed to aligning their lending and investment portfolios with net-zero emissions by 2050 . Given the need for financing that is required to realize the SDGs, such initiatives from the investment sector are crucial. In this chapter, I will address what ESG, SRI, and ethical investments are about, as well as different investment strategies taking these into account. Further dilemmas that arise will be introduced, such as: What is a sustainable sector or product and how this varies depending on peoples' values. The switch from addressing sustainability issues as a risk reduction activity to a business opportunity will also be discussed. Finally, the Norwegian Pension Fund will be used as an example with regards to product-based and conduct-based exclusion.

\subsection{Environmental, Social, and Governance (ESG)}

Traditional financial analysis has always taken into account a variety of factors, like revenues, liabilities, cash, inventory machinery competitors, and so on. ESG are additional factors that can be included in the evaluation. The goal of including these additional factors can be to reduce risk and or improve financial results. 
Typical issues related to the "E" Environmental are energy consumption, pollution, climate change, waste generated, water scarcity, biodiversity, and deforestation

Typical issues related to the "S" Social are child- and forced labor, human rights, community engagement, stakeholder relations, health and safety, employee engagement, customer satisfaction, gender and diversity policies.

Regarding the "G" Governance, the quality of the board and management as well as executive and board compensations, transparency and disclosure, audit, lobbying, political contribution are some examples of content.

Data generated to evaluate the level of corporate performance on the E, S, and G is collected from annual reports, company website, NGO website, stock exchange, Corporate Social Responsibility (CSR)/sustainability reports, new sources/media as well as surveys and interviews.

There are several ESG data providers, Morningstar, Bloomberg, Sustainalytics, and Morgen Stanley Capital International (MSCI). These data providers collect and evaluate the data. Up to 450 ESG data points can be collected. A data point can be for example a type of energy used, level of emissions, waste types generated, volume, production sites, and so on. As data points can be measured in different ways, results will also differ.

A typical approach to calculate an overall ESG score begins by collecting datapoints on corporate sector and operations, and then these are divided into different categories of ESG scores, which are weighted according to own evaluations. Finally, the ESG overall score is provided. This can be presented in the form of letters from AAA for companies and funds with the best ESG performance/score to CCC with companies with the relatively worst ESG performance. The following are some examples of ESG data providers. These companies have traditionally provided company information on financial performance and have since expanded their operations to also cover ESG data.

MSCI (Morgen Stanley Capital International) has more than 150 ESG analysists studying companies' performance. Media coverage, NGO reports, research, and the companies' own sustainability and CSR reporting are sources of data collection (Dieschbourg \& Nussbaum, 2017). 
Bloomberg's database covers more than 11,000 companies and their ESG data is based on MSCI data as well as other data collecting services (Bloomberg Professional Services, n.d.)

Morningstar has more than 400 global employees colleting and processing company data (Schmelzer, 2020). In addition to data from publicly available information, interviews are also conducted to collect information.

Whereas companies like MSCI, Bloomberg, and Morningstar have a long history of providing data for company analysis and have expanded to also provide ESG data, RobecoSAM was founded in 1995 with the purpose of assisting in the process of sustainable investment. To collect ESG data, RobecoSAM mainly uses a questionnaire. Collecting data and answering around 100 questions, which is later evaluated by RobecoSAM, required lots of work for a company. The Dow Jones Sustainability Index (DJSI) RobecoSAM annually publishes a list of best-in-class sustainability benchmarks with the top 10 percent of companies in each sector based on data from RobecoSAM.

The value of the different scores of different companies is only as good as the data on which it is based. If the data put in the analysis is not trustworthy, the outcome or the rating is not trustworthy either. There have been several examples of companies that have been on the top the DJSI list and suddenly were removed when it turned out that the data used to analyze the company was incorrect. Volkswagen for example had a great score on all the above ratings, however, when it turned out that the company had been tampering emission technology to convey better performance, making the point that that ESG scores are not necessarily right. Same with the palm oil giant Golden Agri-Resources, which was also removed from the DJSI after a bribery and corruption scandal in 2018.

Rating providers use different quantitative metrics and weight the results differently. This has led to a variety of results. One company is scored high by one rating company and low by another. It turns out that the correlation between ESG ratings from the six leading ESG providers was 0.61 (Mayor, 2019). This makes it hard for investors to evaluate a company's ESG profile. That combined with the fact that more and more funds have started to name themselves "Green funds" have made investors skeptical. The reputation of such green funds has begun to fringe, 
and the term "greenwashing" employed when referring to such funds. Greenwashing is about conveying a false impression that the company is taking the right environmental measures when in fact the company is deceiving the investors and customers. When claiming to provide "green products," the claim has to be supported with facts and figures. This lack of clarity of what is green and what is not is partly the motivation for the development of the EU Taxonomy, a regulation intended to help stakeholders evaluate more objectively to which extent a company is environmentally sustainable or not and to make it easier for companies to report.

\subsection{The EU Taxonomy}

Given the increasing interest in ESG and "Green funds", it is no wonder that in the last few years we have seen a significant growth in the share of green funds-many renamed as green without any actual changes in companies which consist the funds. It is evident there are many ways to categorize what a sustainable company is, and it is a challenge to understand how the ratings are calculated. Partly as result of this, the EU Taxonomy was launched in 2019.

The EU Taxonomy is part of the plan to finance sustainable growth. Financing sustainable growth is a key element in the European Green Deal. The EU Green Deal, launched in 2019, is a strategy and plan to make EU the first climate-neutral continent by 2050. More investment in climate neutral, energy- and resource-efficient, and circular projects is needed. It is estimated that an additional annual investment of 175 to 290 billion EUR will be needed to reach the climate-neutral goal (European Commission, n.d.-c). The EU Taxonomy provides a common framework for assessing whether or not investments are sustainable and supporting the Green Deal. Such a common framework will help investors to objectively compare corporate performance in the field of sustainability, saving time and money for both companies and investors.

The EU Taxonomy is part of the Sustainable Finance Action Plan (SFAP), a major policy objective by the EU to promote sustainable investment. There are six environmental objectives of the Taxonomy and in order to qualify as "green" the investment needs to contribute to at 
least one of these objectives and do no significant harm on any of the other:

1. Climate change mitigation

2. Climate change adaptation

3. The sustainable use and protection of water and marine resources

4. The transition to a circular economy

5. Pollution prevention and control

6. The protection and restoration of biodiversity and ecosystems (European Commission, n.d.-a)

The Taxonomy is focused on the industries which are the main contributors to climate gas emissions and/or high-emitting sectors: agriculture and forestry, manufacturing, energy, water, transport, information and communications technology (ICT), and buildings.

The Taxonomy is not rating companies as such but provides investors a list of relevant criteria to evaluate companies. This makes it easier to compare companies in terms of sustainability. The Taxonomy is dynamic and will adapt to new knowledge from for example science and experience.

The following is a practical example of how the Taxonomy can contribute to raising capital. A company in the oil and gas industry wants to raise capital to diversify into alternative and renewable energy, like wind power. Since this contributes to climate change mitigation and even a potential reduction in oil production, this fulfils the criteria for issuing an EU Green Bond.

There are several short and practical how-to-do guides for the EU Taxonomy, for example the FAQ-What is the EU Taxonomy and how will it work in practice? (European Commission, n.d.-b). The Taxonomy Technical Report (EU Technical Expert Group on Sustainable Finance, 2019) which consists of several hundred pages can be used as a reference, where each company can assess whether or not their products and services are compatible with and in line with the goals of the Paris Agreement. 


\subsection{To Which Extent Does Focus on Sustainability and Applying the "Right" ESG Impact Profit?}

Traditionally, focus on ESG has either been based on personal value or risk reduction. Supply chains today are vulnerable to natural disasters, climate change, water scarcity, and poor labor conditions and thus represent a risk. A majority of suppliers claim that climate change represents risk which could have a significant negative impact on their operations and earnings.

Hundreds of studies have been conducted to see if it pays off financially to include ESG either to reduce risk or increase turnover and profit. Not surprisingly, this analysis depends on the ESG criteria. What is found, however, is that companies that focus on relevant sustainability issues outperform firms with poor ratings (Khan et al., 2016). And the other way around. That is, if a company involved in the oil and gas industry focuses its sustainability engagement on donating money to poor children in Africa, this is good for society, but not for profit. If the same company focuses its sustainability work on reducing $\mathrm{CO}_{2}$ emissions, that is on materiality issues, the company is more likely to outperform companies involved in non-materiality issues. According to a review of over 2000 empirical studies, including review studies, 90 percent of the studies found a nonnegative ESG-CFP (Corporate Financial Performance) and a large majority of these studies report positive findings (Friede et al., 2015).

There are many examples of negative impact on share price after incidents of corporate irresponsible behavior. Volkswagen tampering with the emission technology led to a significant drop in the shareholder price as was the case with BP after the Deep Horizon disaster. The price of shares in the coal industry furthermore dropped after that Paris agreement was announced. 


\subsection{SRI Strategies}

As is evident from Fig. 9.1, there are different avenues to act on socially responsible investment (SRI) in funds. The most common approach to SRI/ESG funds is, as illustrated in Fig. 9.2, to exclude certain sectors. In the next section, I will address different criteria for exclusion and which ones are most commonly applied. But first, a short review of the different approaches.

The Best-in class approach, or positive screening, is to choose the companies which are the best on ESG performance relative to other industries in the same sector.

Norm-base screening is about selecting companies that perform in accordance with key sustainability standards, such as the UN Global Compact, OECD Guidelines, ILO (International Labor Organization), or the UN sustainable development goals (SDGs).

ESG Integrating in the company investment analysis is conducted either to reduce risk or increase results-or a combination of both. Companies are evaluated based on different ESG factors, and the

Negative /exclusion screening

ESG integration

Corporate engagement and shareholde action

Norms-based screening

Positive/best-in-class screening

Sustainability themed investing

Impact/community investing
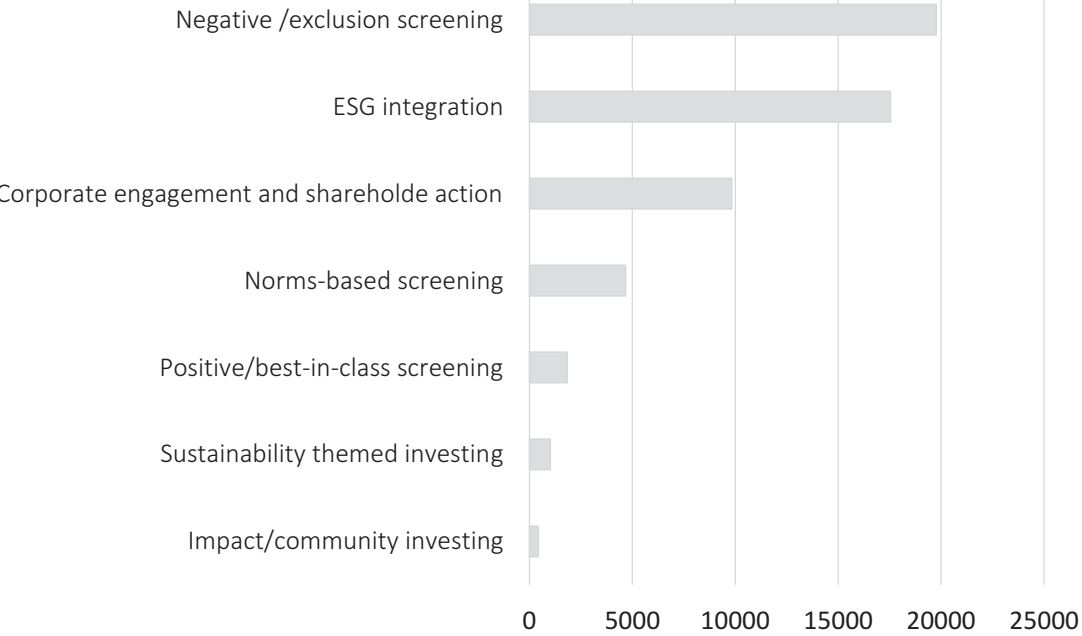

Fig. 9.1 Responsible investment strategies Eurosif 
9 Sustainability and Finance: Environment, Social...

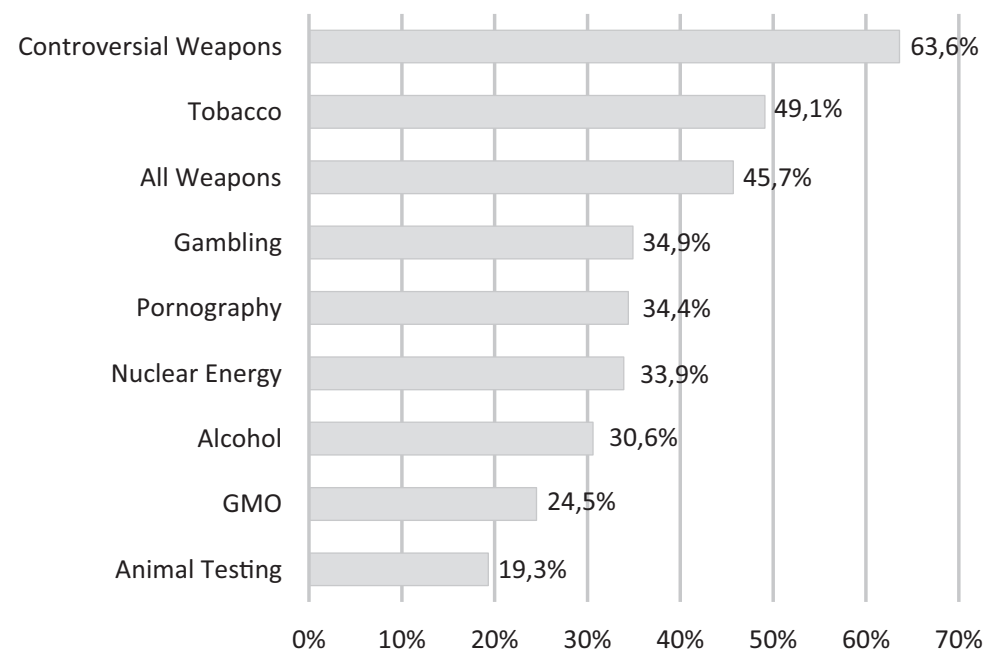

Fig. 9.2 Top exclusion criteria Eurosif

outcome is, as discussed above, dependent upon which ESG elements are selected and how they are weighted. Some of the ESG elements have more impact on returns than others. For example, gender equality in top management might have less of an impact on returns than the degree of $\mathrm{CO}_{2}$ emissions relative to other companies in the same sector.

Engagement and voting are the second most common approaches to responsible investment. This is a long-term process in which investors try to move the company toward a more sustainable way of doing business by using its shareholder voting rights. However, in order to capture these rights, one has to be a shareholder. By excluding certain sectors and companies, the investor loses the voting rights in these companies. By keeping the shares, the investors potentially have a much stronger impact on the company. Sometimes NGOs which are opposed to certain sectors, go in and purchase shares in these companies in order to vote in shareholder meetings. In many cases, investors can have a much stronger impact on sustainable development by pushing "bad" companies in the right direction as opposed to excluding the same companies from their portfolios.

The most common strategy for responsible investment is however the exclusion strategy. The challenge, however, is that there are very many 
different understandings of what sectors or companies are responsible, and should be excluded, and which are not.

Figure 9.2 gives an overview of which sectors are the most common to exclude. And, as evident from the bottom of the figure, Controversial Weapons, that is, nuclear, chemical, and biological weapons and cluster bombs, are the most common industries to exclude.

The second most common industry to exclude is tobacco followed by All Weapons, or weapons in general, Gambling, Pornography, Nuclear Energy, Alcohol, and GMO (genetically modified organisms), and products which are developed using Animal testing. These are the collected rating of exclusion criteria. However, there are individual and cultural differences for opinions on what to exclude.

In a study at BI Norwegian Business School, we asked master's students what would be their main exclusion criteria if they were to choose for their own personal pension portfolios. For them controversial weapons, the most common exclusion criterion in Europe, was on the top of the list. However, the order of the priority list was quite different from what is the trend in Europe in general. For the students in Norway, animal testing is positioned at second place, whereas tobacco is in the second place across Europe. The students were least likely to exclude alcohol from their investment universe. Tobacco, which is a very typical exclusion criterion, was also not so important to exclude. Comparing the list of exclusion criteria in Europe in general to the list drafted by students in Norway illustrates the variation in values and preferences. This is closely related to culture.

\subsection{Investors' Dilemma: What Is a Sustainable and Responsible Company?}

One thing is a personal belief of whether or not investing in alcohol or tobacco is responsible. Another issue is how to invest to solve more general societal challenges in sustainability. Society's main challenges are $\mathrm{CO}_{2}$ emissions and global warming. Industry is working to find alternatives to coal and other fossil fuels as energy sources. Wind power is such 
an alternative. However, even though people in general are positive with regards to wind power, nobody wants to have "it in their backyard".

There are many examples of how Norway's public opposition to onshore wind has threatened the growth wind power generation. The opposition has become so hostile that demonstrators set fire to excavators. The Norwegian Minister of Energy has furthermore been harassed on social media and accused of being a traitor, who should be in jail for supporting building wind power installations in Norway (Taraldsen et al., 2020).

Another industry in which people disagree whether it is sustainable or not is nuclear energy. The nuclear energy generation does not emit any negative climate gases. However, the main challenge in this sector is the accumulation of dangerous waste byproducts and the risk of meltdown. And again, people disagree on the solution. As we see from Fig. 9.2, nuclear energy is one of the most common sectors to exclude from responsible funds. At the same time, Bill Gates, the founder of Microsoft, who is known to be very concerned about environmental issues, and especially global warming, supports nuclear energy as part of the energy solution (Gardner, 2020).

\subsection{The Norwegian Pension Fund}

Norway's oil fund, or the Government Pension Fund Global, is based on income from the oil discovered in the North Sea in 1969. This is one of the world's largest fund with a market value of about 10 trillion NOK (1.3 trillion USD in 2021)_or about two million NOK per each Norwegian citizen. The fund's portfolio includes about 9000 companies in 74 countries and it considers "environmental and social issues, and publish clear expectations of the companies we invest in" (Norges Bank Investment Management, 2019). In 2004, the fund's Council on Ethics was established and over the years different criteria for investment have been implemented. The fund has been a frontrunner for taking ethics and sustainability into account and therefore it is a good example to use 
in illustrating how ESG criteria are applied in practice. As of March 2021, 144 companies are excluded from the fund.

The fund has two major exclusion criteria: product-based and conduct-based.

Product-based exclusion is when companies producing certain types of products are excluded. Conduct-based exclusion is based on a company's behavior, that is, the product can be acceptable, but the conditions under which they are being manufactured are not. Environmental damage and poor working conditions are typical examples of conduct-based exclusions.

Criteria for product-based observation and exclusion of companies (Norges Bank Investment Management, 2016)

(1) The Fund shall not be invested in companies which themselves or through entities they control:

(a) produce weapons that violate fundamental humanitarian principles through their normal use

(b) produce tobacco

(c) sell weapons or military material to states that are subject to investment restrictions on government bonds as described in the management mandate for the Fund, section 3-1(2)(c).

(2) Observation or exclusion may be decided for mining companies and power producers which themselves or through entities they control derive 30 percent or more of their income from thermal coal or base 30 percent or more of their operations on thermal coal.

(3) In assessments pursuant to subsection (2) above, in addition to the company's current share of income or activity from thermal coal, importance shall also be attached to forward-looking assessments, including any plans the company may have that will change the share of its business based on thermal coal and the share of its business based on renewable energy sources.

(4) Recommendations and decisions on exclusion of companies based on subsections (2) and (3) above shall not include a company's green bonds where such are recognized through inclusion in specific indices for green bonds or are verified by a recognized third party. 
There are several sectors which are excluded, but I will only focus on a few of them as examples. The first is weapons that violate fundamental human rights, in line with controversial weapons. This exclusion pertains mostly to nuclear weapons, but also to companies manufacturing chemical and biological weapons and cluster bombs.

Lockheed Martin Corp was for example excluded in 2013 due to its production of key components for nuclear weapons. The company claimed that it was producing "defense weapons". Another example is in the tobacco industry. Philip Morris International Inc. was excluded from the fund in 2010 for its production of tobacco. The third example involves companies which derive more than 30 percent of its income from thermal coal. So, if 25 percent of the company's income is based on coal, it is ok, but if more than 30 percent of its income, the company is excluded. Korea Electric Power Corp is an example of exclusion based on production of coal or coal based in energy. The company was excluded from the fund in 2017.

The following are the criteria for conduct-based observation and exclusion of companies.

Companies may be put under observation or be excluded if there is an unacceptable risk that the company contributes to or is responsible for:

(a) serious or systematic human rights violations, such as murder, torture, deprivation of liberty, forced labor and the worst forms of child labor

(b) serious violations of the rights of individuals in situations of war or conflict

(c) severe environmental damage

(d) acts or omissions that on an aggregate company level lead to unacceptable greenhouse gas emissions

(e) gross corruption

(f) other particularly serious violations of fundamental ethical norms.

Examples of companies excluded based on the above criteria include African Israel Investment Ltd (2014), which was excluded due to serious violations of individuals' rights in situations of war or conflicts associated 
with the company's involvement in building settlements in the West Bank. The Luthai Textile exclusion is based on poor conduct, among other serious violations of human rights, poor working conditions, harassment, restricted access to toilet facilities. This large Chinese company is actually breaking international laws. The company has customers concerned about quality and responsibility in their supply chain, and it can therefore be very negative for Luthai's business and brand to be excluded from the pension fund.

Companies which have been excluded based on non-acceptable conduct can be reintroduced into the fund again if they improve their behavior. And many companies which have been excluded based on conduct, work hard to improve to be included in the fund again. It is not good for the reputation of the company to be excluded from the Norwegian pension fund-even though not all companies agree on the reason for why they are being excluded.

On the fund's website, there is an overview of companies that are excluded or under observation with explanations. It can seem like a paradox when the Norwegian pension fund excludes tobacco, yet cigarettes are sold in food stores across the country. Furthermore, Airbus is a typical commercial aircraft excluded from the fund due to production of nuclear weapons. Yet both Norwegians in general, as well as government officials travel around in aircrafts produced by Airbus.

As mentioned, whether or not a responsible investment strategy renders more or less return depends upon the criteria applied. For many years excluding tobacco led to reduced returns for fund. In one study, we asked a group of 500 people in Norway, a representative sample of the population; "In your own pension fund management, would you choose ethical investment if it means that your pension would be reduced?" 40 percent answered yes and 32 percent answered no. This implies that Norwegians are not all that ethical if it implies reduced earnings. In another group of 500 people, we asked what they thought about Norwegians in general: "In their own pension fund management, do you think most people would choose ethical investment if it means that their own pension will be reduced?" 20 percent answered yes and 56 percent answered no. So, the conclusion is: Norwegians in general prioritize to 
"earn" more pension, relative to taking ethics and responsibility into account if it decreases earnings. And we also think we are more ethical and responsible than other people around us (Ditlev-Simonsen \& Wenstøp, 2016)

\subsection{The Effect of Sustainable Investment Focus in a Long-term Perspective}

From being something mainly of interest to environmentalists and church funds, sustainable finance has become an issue engaging investors and fund managers across the world. This surge in institutional demand and interest for green funds motivates companies to pay attention. If a company is required to report on how it deals with environmental and social issues in order to get access to finance, sustainability issues suddenly become much more relevant and of interest. Investor demand is an important driver for companies to work on sustainability in a more strategic manner.

Having witnessed how poor environmental performance has a negative impact on share price, referring to the Volkswagen case (Chap. 5), the BP Deep Horizon spill which led to a share price loss of 54 percent (Pistilli, 2021), and the decline in coal companies' valuations as renewable energy companies share value increased after the launch of the Paris agreement (Kar-Gupta et al., 2015). But taking sustainability into account is no longer only driven by risk reduction. A lower cost of capital and increased return on investment through sustainable products such as alternative energy, are other effects of a sustainable business model. These are a few of the many examples illustrating that companies have to focus on sustainable business, and also that it can be profitable if done in the right way.

The Value Driven Model presented in Fig. 9.3, is a practical tool developed by the PRI and UNGC that sums up key areas of growth, productivity, and management in which applying sustainability can increase returns on capital. 


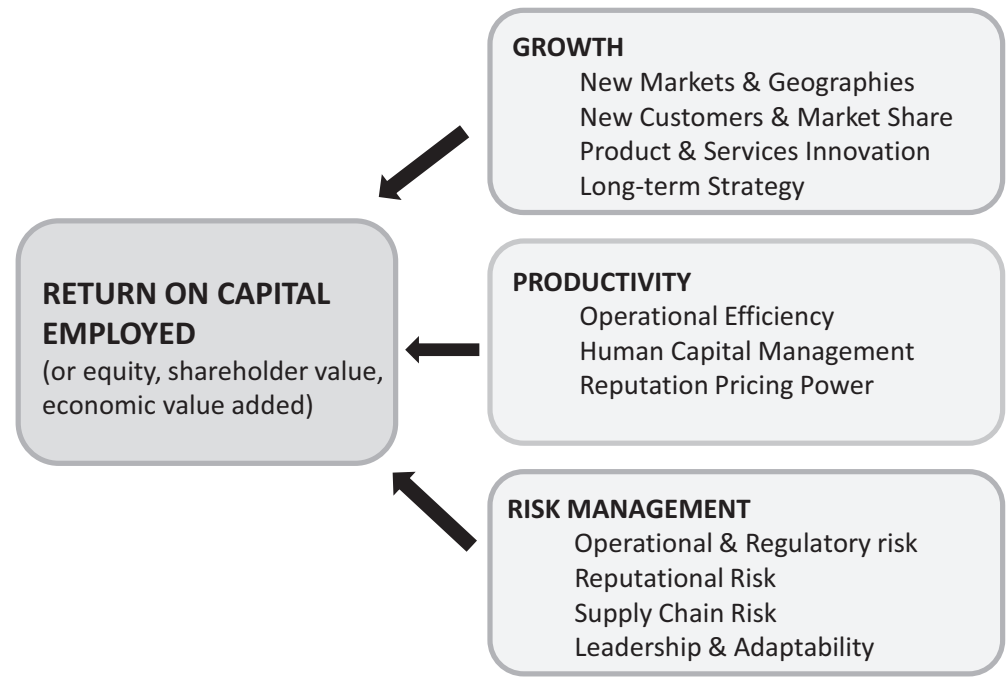

Fig. 9.3 The UN Global Compact and Principles for Responsible Investment (PRI) value driver model

\section{References}

Bloomberg Professional Services. (n.d.). Sustainable finance. Bloomberg Professional Services. https:/www.bloomberg.com/professional/solution/ sustainable-finance/?gclid=Cj0KCQjwhr2FBhDbARIsACjwLo2mRzuHPu TxpfY9WBNFF9YL6_p7G-qDvwAUNCipzqv8Hb-HtTiBKWwaAri ZEALw_wcB\#scores/?utm_medium=Adwords\&utm_campaign=ESG\& utm_source=pdsrch\&utm_content $=$ esgscores $\&$ tactic $=342352$

Dieschbourg, M. T., \& Nussbaum, A. P. (2017). No places to hide thanks to Morningstar, Bloomberg, MSCI and Multiple global data providers. Investments \& Wealth Monitor. https://investmentsandwealth.org/getattachment/fdf4d0e3-adc0-487a-bbe0-624cdefb3b2f/IWM17NovDec-

Ditlev-Simonsen, C. D., \& Wenstøp, F. (2016). Attitudes towards ethical pension management among Norwegians. Beta (Oslo, Norway), 30(2), 100-118. https://doi.org/10.18261/issn.1504-3134-2016-02-01

EU Technical Expert Group on Sustainable Finance. (2019). Taxonomy technical report. https://ec.europa.eu/info/sites/default/files/business_economy_euro/ banking_and_finance/documents/190618-sustainable-finance-teg-reporttaxonomy_en.pdf 
European Commission. (n.d.-a). EU taxonomy for sustainable activities. https:// ec.europa.eu/info/business-economy-euro/banking-and-finance/sustainablefinance/eu-taxonomy-sustainable-activities_en

European Commission. (n.d.-b). FAQ: What is the EU taxonomy and how will it work in practice? https://ec.europa.eu/info/sites/default/files/business_economy_euro/banking_and_finance/documents/sustainable-financetaxonomy-faq_en.pdf

European Commission. (n.d.-c). Financing sustainable growth-factsheet. https://ec.europa.eu/info/sites/default/files/business_economy_euro/banking_and_finance/documents/200108-financing-sustainable-growthfactsheet_en.pdf

Eurosif. (2018). European SRI study 2018.

Friede, G., Busch, T., \& Bassen, A. (2015). ESG and financial performance: Aggregated evidence from more than 2000 empirical studies. Journal of Sustainable Finance \& Investment, 5(4), 210-233. https://doi.org/10.108 0/20430795.2015.1118917

Gardner, T. (2020). Bill Gates' nuclear venture plans reactor to complement solar, wind power boom. Reuters. https://www.reuters.com/article/us-usanuclearpower-terrapower/bill-gates-nuclear-venture-plans-reactorto-complement-solar-wind-power-boom-idINKBN25N2U8?editionredirect $=$ in

Khan, M., Serafeim, G., \& Yoon, A. (2016). Corporate sustainability: First evidence on materiality. The Accounting Review, 91(6), 1697-1724. https://doi. org/10.2308/accr-51383

Mayor, T. (2019). Why ESG ratings vary so widely (and what you can do about it). MIT Thinking Forward Newsletter. https://mitsloan.mit.edu/ideas-madeto-matter/why-esg-ratings-vary-so-widely-and-what-you-can-do-about-it

Norges Bank Investment Management. (2016). Guidelines for observation and exclusion from the fund. https:/www.nbim.no/en/organisation/governancemodel/guidelines-for-observation-and-exclusion-from-the-fund/

Norges Bank Investment Management. (2019, February 27). About the fund. https://www.nbim.no/en/the-fund/about-the-fund/

Pistilli, M. (2021, January 13). What was the BP stock price before the deepwater Horizon spill? Investing News. https://investingnews.com/daily/resourceinvesting/energy-investing/oil-and-gas-investing/bp-oil-stock-pricebefore-spill/

Schmelzer, R. (2020, October 1). Automating data collection for AI at Morningstar. Forbes. 
Taraldsen, L. E., Poulsson, L., \& Starn, J. (2020). Wind farm backlash grows in oil-rich Norway ahead of election. Bloomberg. https://www.bloomberg.com/ news/articles/2020-12-09/wind-farm-backlash-grows-in-oil-richnorway-ahead-of-election

US SIF: The Forum for Sustainable and Responsible Investment. (2020, November 16). The US SIF foundation's biennial "trends report" finds that sustainable investing assets reach $\$ 17.1$ trillion. https://www.ussif.org/blog home.asp?Display= 155

Open Access This chapter is licensed under the terms of the Creative Commons Attribution 4.0 International License (http://creativecommons.org/licenses/ by/4.0/), which permits use, sharing, adaptation, distribution and reproduction in any medium or format, as long as you give appropriate credit to the original author(s) and the source, provide a link to the Creative Commons licence and indicate if changes were made.

The images or other third party material in this chapter are included in the chapter's Creative Commons licence, unless indicated otherwise in a credit line to the material. If material is not included in the chapter's Creative Commons licence and your intended use is not permitted by statutory regulation or exceeds the permitted use, you will need to obtain permission directly from the copyright holder.

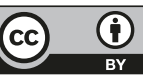

